\title{
Environmental Impact Assessment Study for Wind Turbines in the Desert of Kuwait
}

\author{
Jasem M . Al-Awadhi
}

\begin{abstract}
Wind plays a very important role in developing new energies, producing electricity and improving the environment. This study assesses the main impacts of new wind power project in Kuwait on the environment, including wildlife (mostly avifauna) and public health and safety (Sound and visual impact). Moreover corresponding mitigation measures are put forward in relevance. Long-term benefits of such project will include reduction in greenhouse gases emission, reduction in fuel consumption and costs, reduction in electricity costs to consumers, promotion of alternative sources of energy and tourist attraction.
\end{abstract}

Keywords - Wind, environment, impacts, mitigations.

\section{INTRODUCTION}

$\mathrm{K}_{\mathrm{t} w}$ UWAIT is completely reliant on the burning of fossil fuels for energy generation and water desalination. According to the Ministry of Electricity and Water (MEW) of country, by 2030 Kuwait's energy demand will be tripled. MEW estimates that the amount of fossil fuel available to generate energy in Kuwait will not be sufficient to maintain the country's current rate of social and economic growth. Therefore Changing into a green and low-carbon economy is the objective demand of the sustainable development of the country. Developing green industry with the core of renewable energy, clean technology and pollution prevention, is the main issue to stimulate the implementation of this alter.

The Innovative Renewable Energy Research program (IRE) in Kuwait leads efforts to diversify Kuwait's energy supply by exploring the viability of proven and emerging wind energy technologies that are capable of overcoming the challenges of Kuwait's harsh climate. Wind power is a kind of renewable energy which generates electricity and has tremendous benefits since wind is clean and has very abundant reserve and widely distributed. Producing electricity from wind plays a very important role in developing new energies and improving the environment. It reduces the emission of greenhouse gases effect and preserves the environment. Many countries have intensified developing wind power, a kind of renewable energy which has the most advanced techniques. Germany, Denmark, Holland are in the lead around the world.

The aim of this paper is to discuss the potential impacts and mitigation measures of "Shagaya Wind Plant" on the environment. All provisions of the latest legal acts currently in

Jasem M. Al-Awadhi is with the Kuwait University, Faculty of Science, Department of Earth and Environmental Sciences, P.O. Box 5969, 13060 Safat, Kuwait. force by Kuwait Environment Protection Authority (K-EPA) are complied. The assessment considers the decided plans for the project and addresses current environmental concerns and how to manage them. Indeed, this study provides the negative and positive aspects of the project in order to identify ways to avoid its pitfalls at an early stage (before getting construction permits) and to guarantee the protection and preservation of the environment and available natural resources; in particular those in direct interaction with the health and safety of the potential inhabitants of the area.

\section{II.PROJECT DESCRIPTION}

The project area is located in the western part of the State of Kuwait, approximately $100 \mathrm{~km}$ west from Kuwait City (Fig. 1). The allocated site for the project area is open-desert area with no vegetation coverage. The site is located at elevation of approximately $240 \mathrm{~m}$ from the sea level.

The project includes the engineering, construction and installation of 5 wind turbines of $2 \mathrm{MW}$ each which will be placed in one row and connected in two to three strings to the Substation at a medium voltage level of $11 \mathrm{kV}$ through an underground cable; and the operationalization of the project and its subsequent maintenance for 6 years. The interval of the turbines is 330 meters. The lifespan of the wind turbines is 25 years.

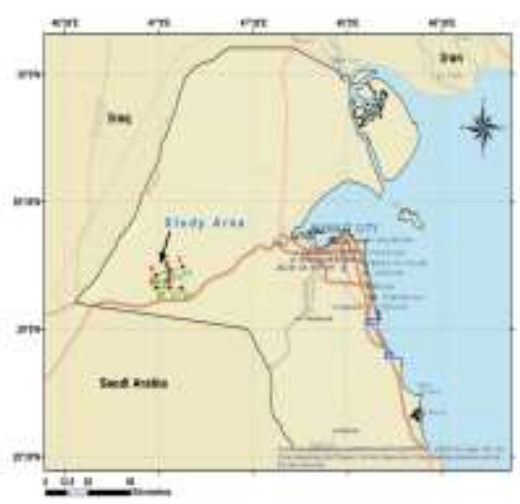

Fig. 1 Location map of the study area

A complete wind turbine generator consists of the following (Fig. 2):

- Wind Turbine Generator (WTG): Machine that produces electrical power using the wind.

- Foundation: Section inserted in platform which is the base and support for the rest of the tower;

- Tower: Main supporting component of the WTG; 
- Nacelle: WTG component which is assembled on top of the tower and in its front part;

- Rotor: Assembly of the hub, nose cone and the 3 blades; is the rotating part of the machine, moved by the wing, that moves the generator axe and therefore produces electrical power.

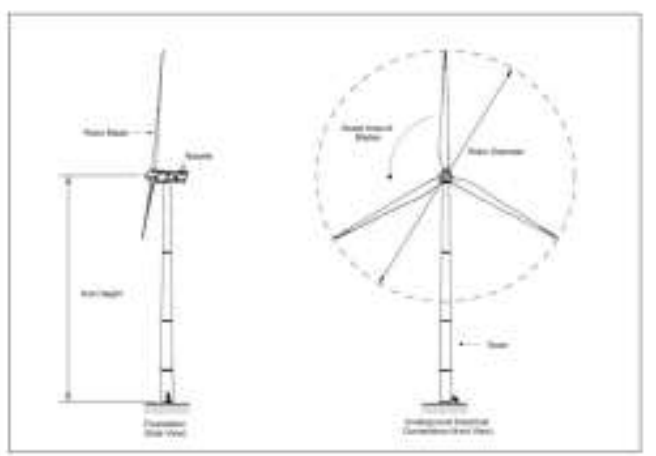

Fig. 2 Complete wind turbine

The following provides a brief description of the construction activities that will occur during the development of the proposed wind plant: Site Access Tracks; Foundations; Site Cabling and Transformer; Civil Site Work; Grid Connection Line; Erection and Installation; Commissioning and Testing; and Clean-Up and Landscaping.

A typical wind turbine requires routine service once or twice per year under maintenance phase. Oil and filters need to be changed, operating components need to be inspected, and bolts need to be torqued. Worn parts need to be routinely repaired or replaced every 5-15 years, depending on the component. Other components may need to be replaced due to environmental or electrical damage.

\section{BASELINE CONDITIONS}

As per the requirement of Kuwait Environmental Protection Law No. 42 of 2014 and Kuwait EPA Executive By-Law of Law 21/1995 comprehensive descriptions of the project environment and the surrounding areas which may be affected by the project have been taken into account. Thus, the Environmental Baseline Study (EBS) for site assessment was conducted in general accordance with these guidelines. The results showed that the allocated site is an open desert area, devoid of any perennial vegetation and has no inland surface water bodies or coastal wetlands. The nearest land use, to the project area, is the new scrap located at about $20 \mathrm{~km}$. The topographic elevation of the site rises gradually from east to the western side (240-250 meter). Geomorphologically, the area is situated at the flank of a paleo plain, with sedimentary sequence of the Arabian monocline [1]. Surface drainage network, in the project area, is not very well developed [2]. The project area is dominated by the upper and lower members of Dibdibba Formation. At the time of investigation, ground water table was not encountered from natural ground level (NGL) to the depth of $30 \mathrm{~m}$ in any of the boreholes conducted by Geotechnical Inspection Company [3]. Seismically the area seems to be quiet with no earthquake observation record [4]. The soil of the study area is mainly Typic Petrogypsids which is permanently unsuitable and moderately saline [5]. No metal contamination was found in the soil samples analyzed by Kuwait University Labs. Recent studies show that the study area is classified among the high wind energy deserts (Fig. 4) [6]. High class of sand encroachment susceptibility is constituted to the study area.

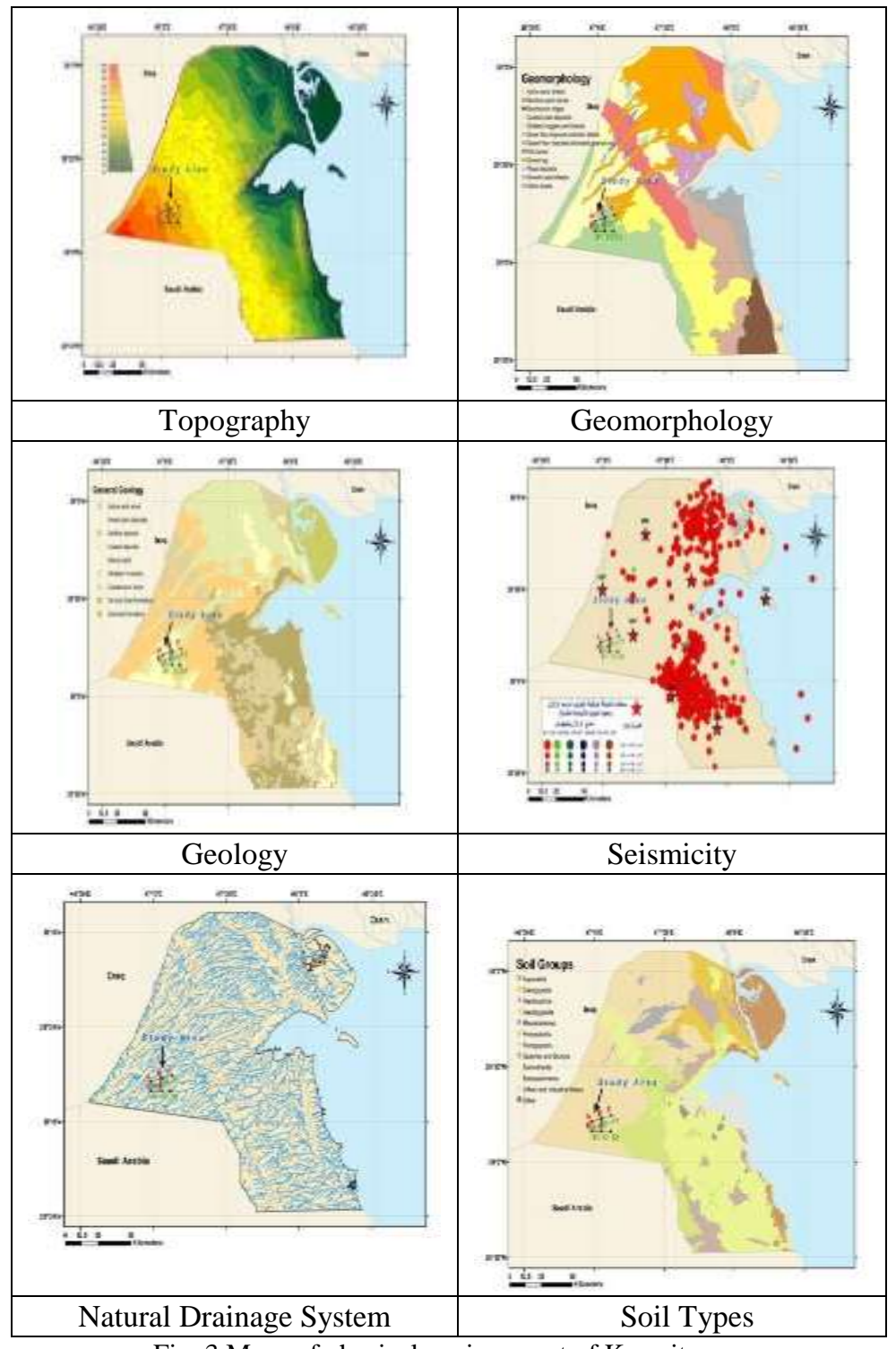

Fig. 3 Maps of physical environment of Kuwait 


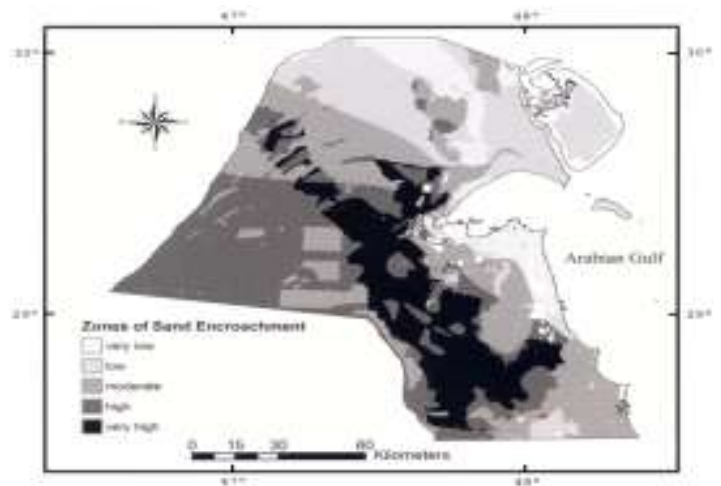

Fig.4 Map of sand encroachment susceptibility in Kuwait

Metrological measurement data features a very strong NNW prevailing wind direction and around $7 \mathrm{~m} / \mathrm{s}$ monthly mean average at $80 \mathrm{~m}$ above ground. The wind conditions are also characterized with a summer peak in wind speed and higher wind speeds during night time (Fig. 5). Based on Air quality monitoring results (11 July 2015 to 21 July 2015) show that all measured pollutants are below stipulated Kuwait EPA Air quality standards and none of the measured gases exceeded the allowable limits. The area is mostly characterized by natural environmental noise with no exceedence of Kuwait EPA noise standards.

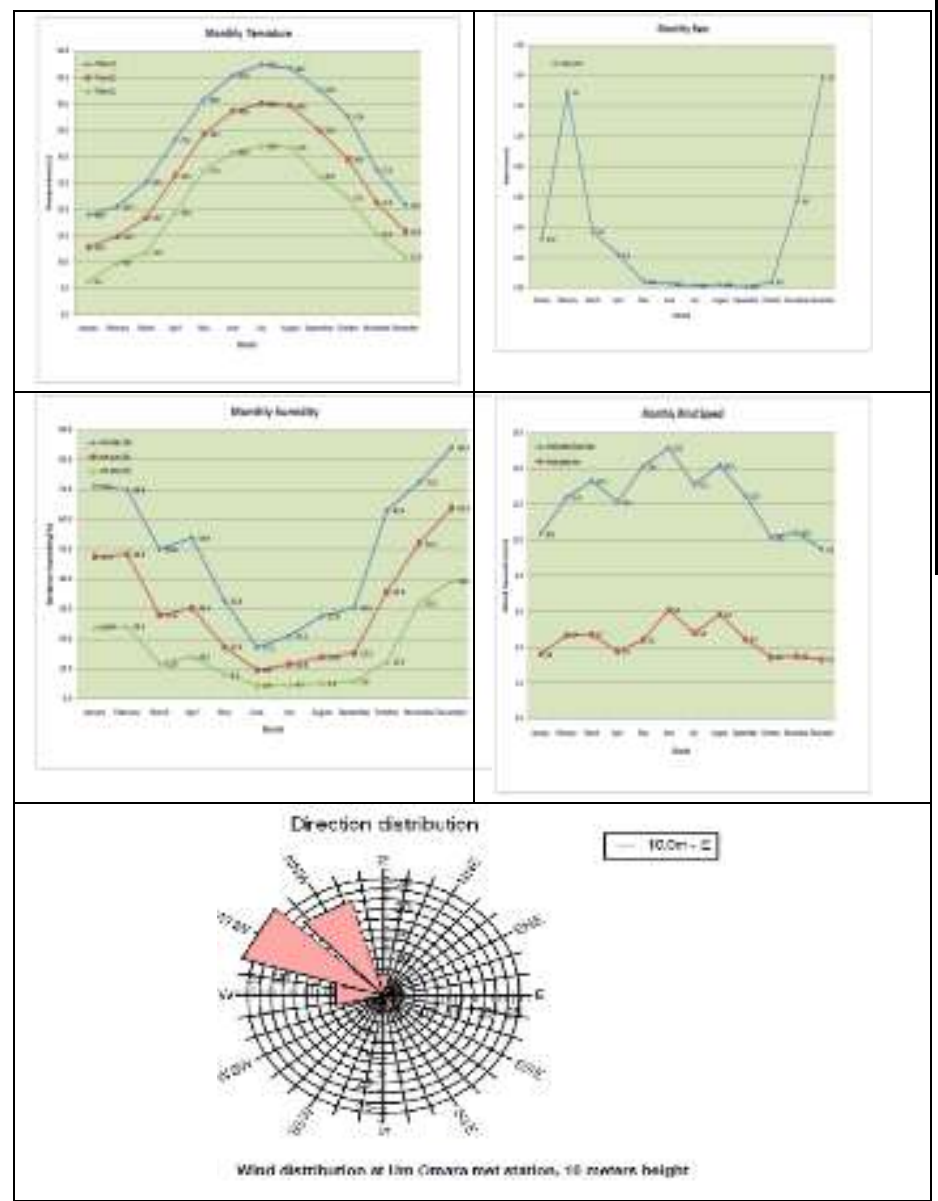

Fig. 5 Monthly variation of climatic conditions for the year 2013

\section{Potential IMPACTS AND Mitigation}

An assessment of environmental effects was completed for all the phases of the proposed wind farm. The negative impacts on soil and topography, air quality, land water during the construction phase are expected to be short term and do not present significant problems, while notable negative impacts of wind turbines during operstion phase will be on public health; i.e., sound and visual impact, and wildlife; mostly avifauna. The following matrix was used for assessment purposes.

TABLE 1

ENVIRONMENTAL ASSESSMENT AND KeY ASSESSMENT EVALUATION MATRIX

\begin{tabular}{|c|c|c|c|}
\hline Extent of Effect & Impact & Nature & Type \\
\hline I- International & Major & St- Short Term & Adverse \\
\hline N- National & Moderate & Lt- Long Term & Beneficial \\
\hline R- Regional & Minor & & \\
\hline D- District & Insignificant & D- Direct & \\
\hline L-Local & Positive & I- Indirect & \\
\hline & Negligible & T- Temporary & \\
\hline & & P- Permanent & \\
\hline
\end{tabular}

\begin{tabular}{|c|c|c|c|c|c|}
\hline & \multicolumn{4}{|c|}{ Sensitivity } \\
\hline & & Very low & Low & Med & High \\
\hline \multirow{4}{*}{ Magnitude } & $\begin{array}{l}\text { Very } \\
\text { Low }\end{array}$ & Insignificant & Insignificant & Minor & Minor \\
\hline & Low & Insignificant & Minor & Minor & Moderate \\
\hline & Med & Minor & Minor & Moderate & Major \\
\hline & High & Minor & Moderate & Major & Major \\
\hline Major & \multicolumn{5}{|c|}{$\begin{array}{l}\text { Very large or large change in environmental conditions. } \\
\text { Effects, both adverse and beneficial, which are likely to be } \\
\text { important considerations at a regional or district level because } \\
\text { they contribute to achieving national, regional or local } \\
\text { objectives, or, could result in exceeding of statutory objectives } \\
\text { and/or breaches of legislation. }\end{array}$} \\
\hline Moderate & \multicolumn{5}{|c|}{$\begin{array}{l}\text { Intermediate change in environmental. Effects, which are } \\
\text { likely to be important considerations at a local level. }\end{array}$} \\
\hline Minor & \multicolumn{5}{|c|}{$\begin{array}{l}\text { Small change in environmental conditions. These effects may } \\
\text { be raised as local issues but are unlikely to be of importance } \\
\text { in the decision making process. }\end{array}$} \\
\hline Insignificant & \multicolumn{5}{|c|}{$\begin{array}{l}\text { No discernable change in environmental conditions. An effect } \\
\text { that is likely to have a negligible or neutral influence, } \\
\text { irrespective of other effects. }\end{array}$} \\
\hline
\end{tabular}

A summary of the potential impacts associated with the project during the construction and operation phases is presented in Table 2 and Table 3, respectively. 
TABLE 2

A SUMMARY OF THE POTENTIAL IMPACTS ASSOCIATED WITH THE PROJECT DURING THE CONSTRUCTION PHASE

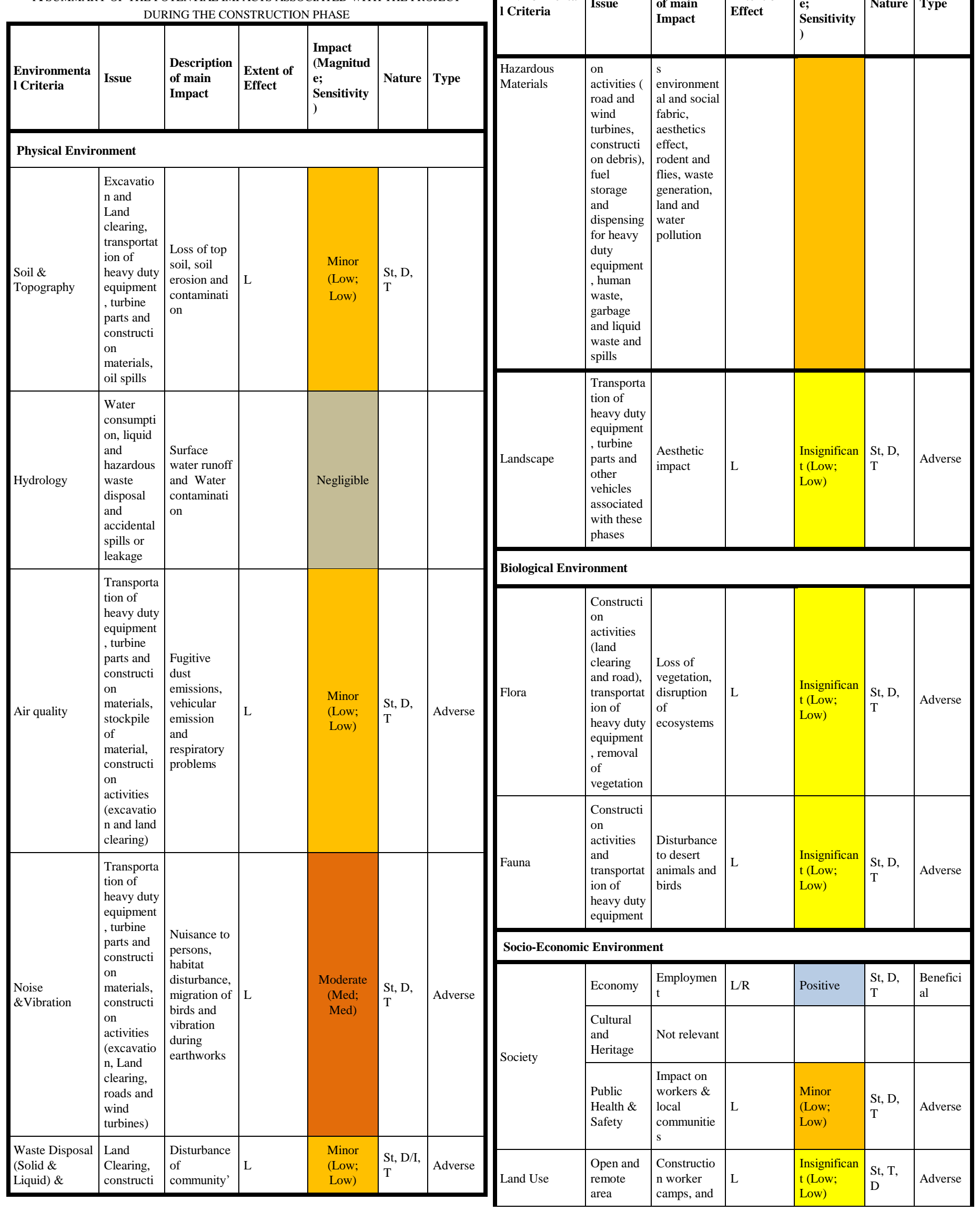




\begin{tabular}{|c|c|c|c|c|c|c|}
\hline $\begin{array}{l}\text { Environmenta } \\
\text { l Criteria }\end{array}$ & Issue & $\begin{array}{l}\text { Description } \\
\text { of main } \\
\text { Impact }\end{array}$ & $\begin{array}{l}\text { Extent of } \\
\text { Effect }\end{array}$ & $\begin{array}{l}\text { Impact } \\
\text { (Magnitud } \\
\text { e; } \\
\text { Sensitivity } \\
\text { ) }\end{array}$ & Nature & Туре \\
\hline & & $\begin{array}{l}\text { improper } \\
\text { methods } \\
\text { used for } \\
\text { disposal of } \\
\text { solid wastes } \\
\text { and } \\
\text { effluents }\end{array}$ & & & & \\
\hline Traffic & $\begin{array}{l}\text { Increased } \\
\text { traffic } \\
\text { movement }\end{array}$ & $\begin{array}{l}\text { Traffic } \\
\text { disruption- } \\
\text { congestion, } \\
\text { over use of } \\
\text { roads and } \\
\text { motor } \\
\text { vehicle } \\
\text { accident }\end{array}$ & $\mathrm{L}$ & $\begin{array}{l}\text { Minor } \\
\text { (Low; } \\
\text { Low) }\end{array}$ & $\begin{array}{l}\text { St, D, } \\
\text { T }\end{array}$ & Adverse \\
\hline
\end{tabular}

TABLE 3

A SUMMARY OF THE POTENTIAL IMPACTS ASSOCIATED WITH THE PROJECT

\begin{tabular}{|c|c|c|c|c|c|c|}
\hline $\begin{array}{l}\text { Environment } \\
\text { al Criteria }\end{array}$ & Issue & $\begin{array}{l}\text { Description } \\
\text { of main } \\
\text { Impact }\end{array}$ & $\begin{array}{l}\text { Extent of } \\
\text { Effect }\end{array}$ & Impact & Nature & Type \\
\hline \multicolumn{7}{|c|}{ Physical Environment } \\
\hline $\begin{array}{l}\text { Soil \& } \\
\text { Topography }\end{array}$ & $\begin{array}{l}\text { No } \\
\text { change }\end{array}$ & $\begin{array}{l}\text { Soil } \\
\text { contaminati } \\
\text { on due to } \\
\text { maintenanc } \\
\text { e activities } \\
\text { (oil } \\
\text { spills/leaks) }\end{array}$ & $\mathrm{L}$ & $\begin{array}{l}\text { Negligibl } \\
\mathrm{e}\end{array}$ & & \\
\hline Air quality & & $\begin{array}{l}\text { Reduction } \\
\text { in } \\
\text { greenhouse } \\
\text { gas } \\
\text { emissions }\end{array}$ & $\mathrm{L} / \mathrm{R}$ & Positive & $\begin{array}{l}\text { Lt, D, } \\
P\end{array}$ & $\begin{array}{l}\text { Benefici } \\
\text { al }\end{array}$ \\
\hline $\begin{array}{l}\text { Noise \& } \\
\text { vibration }\end{array}$ & $\begin{array}{l}\text { Mechani } \\
\text { cal \& } \\
\text { electrical } \\
\text { noise } \\
\text { from } \\
\text { operation } \\
\text { of wind } \\
\text { turbines } \\
\text { and } \\
\text { noise } \\
\text { created } \\
\text { by the } \\
\text { rotors }\end{array}$ & $\begin{array}{l}\text { Nuisance } \\
\text { to } \\
\text { persons, } \\
\text { habitat } \\
\text { disturbanc } \\
\text { e and } \\
\text { migration } \\
\text { of birds }\end{array}$ & $L$ & $\begin{array}{l}\text { Moderate } \\
\text { (Med; } \\
\text { Med) }\end{array}$ & $\begin{array}{l}\text { Lt, D, } \\
P\end{array}$ & $\begin{array}{l}\text { Advers } \\
\mathrm{e}\end{array}$ \\
\hline $\begin{array}{l}\text { Waste } \\
\text { Disposal } \\
\text { (Solid \& } \\
\text { Liquid)\& } \\
\text { Hazardous } \\
\text { Materials }\end{array}$ & $\begin{array}{l}\text { Used } \\
\text { storage } \\
\text { batteries } \\
\text { and used } \\
\text { oil, } \\
\text { spills/lea } \\
\text { ks }\end{array}$ & $\begin{array}{l}\text { Land and } \\
\text { water } \\
\text { pollution, } \\
\text { aesthetic } \\
\text { impacts }\end{array}$ & $\mathrm{L}$ & $\begin{array}{l}\text { Insignific } \\
\text { ant (Low; } \\
\text { Low) }\end{array}$ & St, I, P & Adverse \\
\hline Landscape & $\begin{array}{l}\text { Sited } \\
\text { turbines } \\
\text { influence } \\
\text { the } \\
\text { aesthetic } \\
\text { value of } \\
\text { the } \\
\text { landscape }\end{array}$ & $\begin{array}{l}\text { Visual } \\
\text { impact }\end{array}$ & $\mathrm{L}$ & Positive & $\begin{array}{l}\text { Lt, D, } \\
P\end{array}$ & $\begin{array}{l}\text { Benefici } \\
\text { al }\end{array}$ \\
\hline Biological E & onment & & & & & \\
\hline
\end{tabular}

\begin{tabular}{|c|c|c|c|c|c|c|}
\hline $\begin{array}{l}\text { Environment } \\
\text { al Criteria }\end{array}$ & Issue & $\begin{array}{l}\text { Description } \\
\text { of main } \\
\text { Impact }\end{array}$ & $\begin{array}{l}\text { Extent of } \\
\text { Effect }\end{array}$ & Impact & Nature & Type \\
\hline Flora & $\begin{array}{l}\text { Changes } \\
\text { into } \\
\text { protected } \\
\text { area }\end{array}$ & $\begin{array}{c}\text { Desert } \\
\text { greening, } \\
\text { Conservativ } \\
\text { e area }\end{array}$ & $\mathrm{L}$ & Positive & $\begin{array}{l}\mathrm{Lt}, \mathrm{D}, \\
\mathrm{P}\end{array}$ & $\begin{array}{l}\text { Benefici } \\
\text { al }\end{array}$ \\
\hline \multirow[t]{2}{*}{ Fauna } & $\begin{array}{l}\text { Turbines } \\
\text { operation } \\
\text { effect on } \\
\text { avifauna }\end{array}$ & $\begin{array}{l}\text { Habitat } \\
\text { changes, } \\
\text { disruption } \\
\text { in } \\
\text { avifauna } \\
\text { flight } \\
\text { patterns } \\
\text { and } \\
\text { collision } \\
\text { mortality }\end{array}$ & $\mathrm{L} / \mathrm{R}$ & $\begin{array}{l}\text { Minor } \\
\text { (Low; } \\
\text { Low) }\end{array}$ & $\begin{array}{l}\text { Lt, D, } \\
P\end{array}$ & Adverse \\
\hline & $\begin{array}{l}\text { Other } \\
\text { fauna }\end{array}$ & $\begin{array}{l}\text { Enhance } \\
\text { biodiversit } \\
\text { y as a } \\
\text { result of } \\
\text { protected } \\
\text { area }\end{array}$ & $\mathrm{L}$ & Positive & $\begin{array}{l}\text { Lt, D, } \\
P\end{array}$ & $\begin{array}{l}\text { Benefici } \\
\text { al }\end{array}$ \\
\hline \multicolumn{7}{|c|}{ Socio-Economic Environment } \\
\hline \multirow[b]{3}{*}{ Society } & Economy & $\begin{array}{l}\text { Reduction } \\
\text { in fuel cost } \\
\text { and } \\
\text { demand, } \\
\text { promotion } \\
\text { of use of } \\
\text { alternative } \\
\text { energy and } \\
\text { potential of } \\
\text { tourist } \\
\text { attraction }\end{array}$ & $\mathrm{I} / \mathrm{N} / \mathrm{R} / \mathrm{L}$ & Positive & $\begin{array}{l}\text { Lt, } \\
\text { D/I, P }\end{array}$ & $\begin{array}{l}\text { Benefici } \\
\text { al }\end{array}$ \\
\hline & $\begin{array}{l}\text { Cultural } \\
\text { and } \\
\text { Heritage }\end{array}$ & $\begin{array}{l}\text { Not } \\
\text { relevant }\end{array}$ & & & & \\
\hline & $\begin{array}{l}\text { Public } \\
\text { Health \& } \\
\text { Safety }\end{array}$ & $\begin{array}{l}\text { Flickering, } \\
\text { electromag } \\
\text { netic } \\
\text { interference } \\
\text { which can } \\
\text { affect radar } \\
\text { and radio } \\
\text { communica } \\
\text { tion and } \\
\text { light, } \\
\text { lightning } \\
\text { strikes can } \\
\text { cause fire, } \\
\text { damage to } \\
\text { wind } \\
\text { turbines } \\
\text { and } \\
\text { disruption } \\
\text { in } \\
\text { electricity } \\
\text { supplies }\end{array}$ & $\mathrm{L} / \mathrm{R}$ & $\begin{array}{l}\text { Minor } \\
\text { (Low; } \\
\text { Low) }\end{array}$ & $\begin{array}{l}\mathrm{Lt}, \mathrm{I}, \\
\mathrm{P}\end{array}$ & Adverse \\
\hline Land Use & $\begin{array}{l}\text { Alteration } \\
\text { of } \\
\text { developm } \\
\text { ent and } \\
\text { land use } \\
\text { in the area }\end{array}$ & $\begin{array}{l}\text { Changes } \\
\text { into } \\
\text { protected } \\
\text { (conserve) } \\
\text { area }\end{array}$ & $\mathrm{L}$ & Positive & $\begin{array}{l}\mathrm{Lt}, \mathrm{D}, \\
\mathrm{P}\end{array}$ & $\begin{array}{l}\text { Benefici } \\
\text { al }\end{array}$ \\
\hline \multirow[t]{2}{*}{ Traffic } & Air traffic & $\begin{array}{l}\text { Disruption } \\
\text { of air traffic } \\
\text { and plane } \\
\text { crashes }\end{array}$ & & $\begin{array}{l}\text { Negligibl } \\
\mathrm{e}\end{array}$ & & \\
\hline & $\begin{array}{l}\text { Traffic by } \\
\text { public }\end{array}$ & $\begin{array}{l}\text { Not } \\
\text { relevant }\end{array}$ & & & & \\
\hline
\end{tabular}




\section{A. Noise}

There are no residences in the project area as it is primarily open-desert area and noise from construction is not expected to impact anyone outside the boundary of the project site. Concerns about noise from a wind turbine could be due to operating the wind turbines. There are two distinct noise sources associated with the operation of wind turbines. Aerodynamic noise which is caused by blades passing through the air and mechanical noise which is created by the operation of mechanical elements in the wind power generator. It's expected that generators make noise of $105.8 \mathrm{~dB}$ (A) during the operation.

The calculation of noise emission for a wind speed of $10 \mathrm{~m} / \mathrm{s}$, using the maximum sound power curve at $78 \mathrm{~m}$ hub height $(105.8 \mathrm{~dB}(\mathrm{~A}))$ for five wind turbines has been carried out using WindPRO 3.0 software. The result shows the ISO $35,40,45,50$ and $55 \mathrm{~dB}$ (A) noise curves for the installation of G97-2.0MW IIA/IIIA wind turbines (Fig. 6). The calculated noise levels do not exceed $55 \mathrm{~dB}$ (A), thus noise impact is unlikely to be a significant problem for the proposed site.

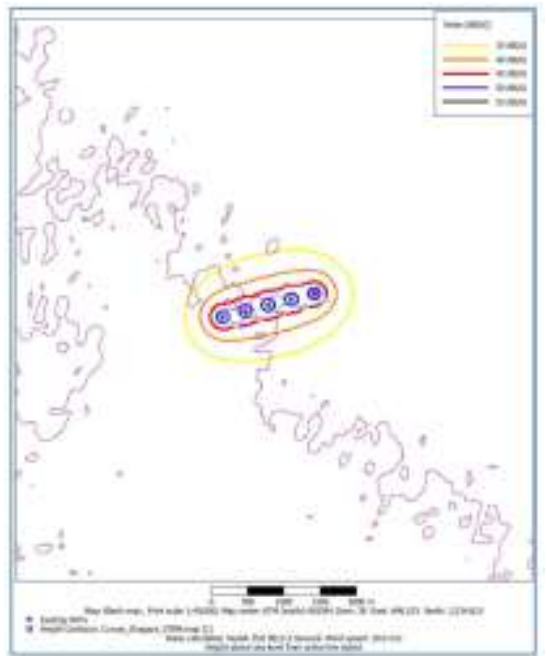

Fig. 6 Noise curves at wind farm during the operational phase

Control measures of noise- Balance and vibration reduction should be considered, when the equipment is installed. The spread of noise should be blocked by placing noise barriers on the border area and boundary. However Specific mitigation options to reduce noise have been incorporated into the design and structure of the wind turbines and therefore the wind farm will meet the recommended criteria for noise on public health.

\section{B. Lighting}

The shadow of the rotating blades fan will produce lighting effects in a certain range which is known as shadow flicker. This effect lasts only for a short period and happens only in certain specific combined circumstances, such as when the sun is shining at a low angle, when the turbine is positioned directly between the sun and the affected property upon which the shadow is cast.
A primary factor which determines the intensity of shadow flicker at a potential receptor (i.e. the facility where the shadow falls) is the distance of the wind turbine from that receptor. Acceptable limits are typically 30 minutes per day or 30 hours per year within a 500m range of dwellings [7].

The shadow-flicker modeling analysis was conducted using WindPRO 3.0 software, following the worst case scenario, which assumes the sun always shining (from sun rise to sun set), wind turbine always running and rotor oriented perpendicular to neighbor wind turbine (Fig. 7). Based on modeling analysis and the zone of influence which is almost $1 \mathrm{~km}$ (there are no residences within the zone of influence), the potential for shadow flicker of current wind turbines is very low; because the project site is uninhabited and there are no sensitive areas within $500 \mathrm{~m}$ radios of the turbines.

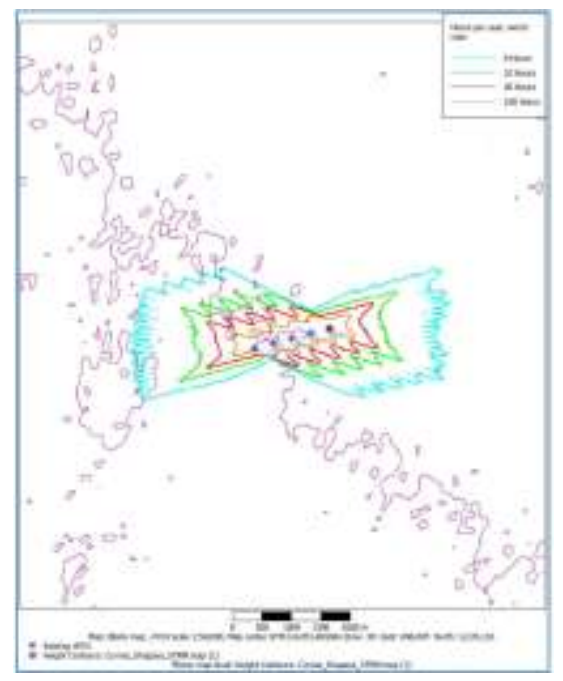

Fig. 7 Shadow map in hour/year at wind farm during the operational phase

Control measures of lighting- In order to avoid effecting on surrounding by lighting; the site of wind power project has been selected away from the residential areas and from other environmentally-sensitive areas. Even so flickering annoyance can be minimized with planting trees or installing window awnings, or limiting wind turbine operations when certain lighting conditions exist such as by turning off a particular turbine at certain times. Future development should also consider the adequate distance from the turbines.

\section{Wildlife}

The mechanical noise and the wake flow made by the wind power units will have certain impact on birds' migration. Noise disturbance during operational phase leads to the minimal displacement of birds from the development site and its surroundings. There is also possibility of bird and bat mortality due to collision. Since the project site is located approximately $100 \mathrm{~km}$ west of the coastal zone where a sea of sand exists, then the site acts as a non-vapor root to most migrating birds. Accordingly, these impacts are relatively low and do not pose a threat to species populations and migratory birds. 
Control measures of the impact on wildlife- Birds' migration should be paid close attention to, because the operation of wind turbines has certain impact on it .Additional research into wildlife behavior (radar) and, the use of variable speed operations without significantly affecting power production might reduce collision mortality [8]. Effective monitoring is also required to provide evidence of compliance with environmental conditions, such as noise limits or wildlife conservation.

\section{Overall}

Electricity generated from wind is a renewable resource. By the utilization of modern technology wind can be captured efficiently. The energy produced by the wind mills does not generate any greenhouse gases or any harmful gases and it is generally considered as a technology that has positive effects on the conservation of the environment. They occupy only small plot of land. The effect on indigenous flora and fauna is minimal. Hence it can be made operational without causing much change to the land use pattern.

\section{V.CONCLUSIONS}

For the sake of the planet, rural economic revitalization, and resource preservation we must promote a renewable energy economy. Wind power can be a cornerstone of that sustainable energy in future. It is affordable, provides jobs, substantial revenue, and treads lightly on our environment without causing adverse effects like environmental pollution, hazardous waste generation and natural resources depletion. Embracing wind energy today will lay the foundation for a healthy tomorrow. In general the use of wind power has a light environmental footprint compared to the much more serious effects of conventional electricity generation, which affects climate change and disturbs the natural balance.

\section{ACKNOWLEDGMENT}

The author gratefully acknowledges the assistance, cooperation and logistical support provided by Ms Shahrzad Gashasi from Solutions for Environmental Consultancy Office.

\section{REFERENCES}

[1] F.I. Khalaf, I. M. Gharib, and M. Z. Al-Hashash, "Types and characteristics of the recent surface deposits of Kuwait, Arabian Gulf", Journal of Arid Environments, vol. 7, pp. 9-33, 1984.

[2] J. Al-Sulaimi, F. Khalaf, and A. Mukhopadhyay, "Geomorphological analysis of paleo drainage systems and their environmental implications in the desert of Kuwait", Environmental Geology, vol. 9, no. 1-2, pp. 94-111, 1997. http://dx.doi.org/10.1007/s002540050108

[3] Gulf Inspection International Company, "Report (Ref/ 201302 003) on the ground investigation works for Shagaya renewable energy power plant" Kuwait, 2103, unpublished.

[4] J. M. Al-Awadhi, and V. Medzi, "The seismicity of the Kuwait Subregion", Seismological Research Letter, vol. 72, pp. 462-473, 2001. http://dx.doi.org/10.1785/gssrl.72.4.462

[5] S. A. Omar, R. Misak, P. King, Sh. A. Shahid, H. Abo-Rizq, G. Grealish, W. Roy, "Mapping the vegetation of Kuwait through reconnaissance soil survey", Journal of Arid Environments, vol. 48, pp.341-55, 2001 http://dx.doi.org/10.1006/jare.2000.0740

[6] A. Al-Hellal, and J. M. Al-Awadhi, "Assessment of sand encroachment in Kuwait Using GIS”, Environmental Geology, vol. 49, pp. 960-967, 2006. http://dx.doi.org/10.1007/s00254-005-0134-8

[7] Anja Neubert, Andrew Peel and Wolfgang Schelz, "Shadow flicker validation \&Mitigation", 2010, unpublished.

[8] E. B. Arnett, M. M. P. Huso, J. P. Hayes, and M. Schirmacher, "Effectiveness of changing wind turbine cut-in speed to reduce bat fatalities at wind facilities", 2010, unpublished. 